Ritrýnd grein birt 31. desember 2020

\title{
Tengslin við heimilin trosnuðu merkilega lítið í fyrstu bylgju COVID-19 Sjónarhorn stjórnenda og grunnskólakennara
}

\author{
Kristín Jónsdóttir \\ Abstract Um höfund \\ About the author \\ Heimildir
}

Viðvera nemenda var minnkuð í langflestum grunnskólum vorið 2020 pegar fyrsta bylgja COVID-19 gekk yfir en á móti kom að upplýsingagjöf til foreldra var aukin og fjarkennsla tekin upp. Skipulag viðveru og fjarkennslu var mismunandi milli skóla og sveitarfélaga en allir væntu pess að nemendur lærðu heimavið.

Pessi rannsókn beinist að viðhorfum skólastjórnenda og kennara. Peir svöruðu spurningakönnun í apríl 2020 en svör bárust frá 151 grunnskóla af 170 skólum á landinu öllu. Niðurstöður sýndu að stjórnendum og kennurum var ljóst að aðstæður nemenda til náms heimavið væru mismunandi. Peir lögðu mikla vinnu í að halda uppi kennslu og búa nemendur út með námsefni og verkefni. Kennarar vörðu meiri tíma en í venjulegu árferði í undirbúning kennslu og kennsluna sjálfa, sem og í upplýsingamiðlun og samskipti við heimilin. Stjórnendur og kennarar voru ánægðir með hvernig kennslan var á heildina litið en peim fannst nokkuð skorta á að pátttaka foreldra í námi barna sinna væri eins góð og kennslan á pessum tíma. Bæði kennarar og stjórnendur lýstu áhyggjum af slakri mætingu nemenda af erlendum uppruna og peirra sem hafa veikt bakland. Tengsl skóla og heimila styrktust frekar en veiktust á pessu tímabili prátt fyrir álag í samfélaginu. Ályktun höfundar byggir á að (1) starfsfólk skóla lagði sig fram um að halda skólunum opnum og stýra góðri og vel undirbúinni kennslu af fagmennsku um leið og bað fékk skýrari mynd af aðstæðum nemenda heimavið; (2) svo virðist sem foreldrar hafi fengið meiri innsýn í fjölbreytt og krefjandi viðfangsefni grunnskólanáms og oftast sýnt skólafólkinu pakklæti og virðingu; (3) samskipti heimila og skóla jukust verulega í flestum tilvikum og kennarar og foreldrar unnu saman eftir nýjum leiðum. Tengsl kennara við nemendur úr viðkvæmum hópum rofnuðu frekar en við skólasystkin peirra svo neikvæð áhrif fyrstu bylgju faraldursins virðast hafa bitnað harðast á peim.

Efnisorð: COVID-19, tengsl heimila og skóla, grunnskólar, jafnrétti, skólapróun

\section{Inngangur}

Undir lok febrúar 2020 greindust fyrstu Íslendingarnir með COVID-19 og pann 13. mars var lýst yfir neyðarástandi sem stóð til 4. maí. Grunnskólastarf var endurskipulagt í miklum flýti; nemendur mættu á mismunandi tímum og mismikið í sóttvarnaskyni. Til að bæta upp fyrir skerta viðveru innan veggja skólanna bjuggu kennarar nemendur sína út með námsefni, verkefni og áætlanir til að peir gætu stundað grunnskólanámið að hluta til heima. Mátti sjá og heyra talað um heimakennslu og heimaskóla (Ingvi Hrannar Ómarsson, 2020). Heimanám fékk margs konar nýja merkingu á pessu tímabili en í pessari grein verður frekar talað um nám nemenda heimavið, til aðgreiningar frá heimanámi eins og algengast var fyrir faraldurinn. 


\section{Fyrstu viðbrögð}

Skipulag viðveru og fjarkennslu var mjög mismunandi milli skóla og milli sveitarfélaga en allir væntu pess að nemendur lærðu heima. Margir kennarar nýttu sér upplýsingatækni í mun meira mæli en áður og svo virðist sem kennsluskipulag hafi víða orðið að blöndu af námi heimavið og námi með viðveru í skólanum, í mismunandi hlutföllum eftir aldri nemenda (Kennarasamband Íslands, 2020).

Foreldrar grunnskólabarna eru ekki einsleitur hópur frekar en börnin sjálf og breytingar á starfsemi skóla komu við fjölskyldur á ólíka vegu. Á samfélagsmiðlum mátti sjá foreldra sem lýstu námi barna heimavið sem ánægjulegri viðbót við samverustundir fjölskyldunnar. Annars staðar fréttist af börnum sem upplifðu depurð og fundu hvergi næði til að læra heima. Yfirvöld létu pýða upplýsingarit, Lykilskilaboð og forvarnaraðgerðir vegna COVID-19 i skólum (UNICEF, 2020) sem m.a. var ætlað að draga úr kvíða og streitu meðal nemenda, með fræðslu og forvörnum.

Viðbrögðum grunnskóla landsins var stýrt af skólastjórnendum og rekstraraðilum sem í flestum tilfellum eru sveitarfélögin en í grunnskólum sem aðrir aðilar reka eru um 3\% nemenda. Menntaog menningarmálaráðuneytið fundaði reglulega með forsvarsmönnum skólakerfisins og tók virkan pátt í umræðum um viðbrögðin. Pegar sóttvarnareglur voru hertar verulega pann 20. mars 2020 gaf heilbrigðisráðuneytið í samvinnu við mennta- og menningarmálaráðuneytið út leiðbeinandi viðmið um íprótta- og æskulýðsstarf í ljósi takmörkunar á skólastarfi og samkomum. Í peim er aðallega fjallað um ípróttirnar en um skólastarfið segir:

Kennsla í leik- og grunnskólum fer nú fram í litlum hópum og leitast er við að ekki verði blöndun milli pessara hópa til að hægja eins og unnt er á útbreiðslu COVID-19 sjúkdómsins.

(Heilbrigðisráðuneytið og mennta- og menningarmálaráðuneytið, 2020)

Sums staðar erlendis var viðbrögðum við COVID-19 í skólum meira miðstýrt. Í Noregi til dæmis var tveimur stofnunum, annarri sem svipar til Menntamálastofnunar og hinni til Landlæknisembættisins, falið að móta saman sérstakar reglur fyrir grunnskóla um sóttvarnir og eftirlit vegna faraldursins (Johansen o.fl., 2020). Leik- og grunnskólum í Noregi var lokað 13. mars 2020 og peir opnaðir rólega aftur eftir sex vikna hlé; leikskólar pann 20. apríl, 1.-7. bekkur grunnskóla 27. apríl og unglingadeildir 11. maí. Pá var skólunum uppálagt að fylgja reglum sem meðal annars fjölluðu um smitvarnir, hámarksfjölda í hverjum nemendahópi, að hópar skyldu halda sér í frístundastarfi eftir að skóladegi lyki og að ákjósanlegt væri að blanda saman staðkennslu og fjarkennslu par sem pví yrði við komið (Johansen o.fl., 2020). Með fylgdu gátlistar, meðal annars einn um prif og annar um hvaða börnum ætti af heilsufarsástæðum að beina frá pví að mæta í skóla. Í grein, sem skrifuð var af fagfólki beggja stofnana, var bent á að takmarkaðar sannanir væru fyrir gagnsemi skólalokana til pess að hefta útbreiðslu COVID-19 en vitað væri að lokunum fylgdi aukin hætta á ójöfnuði milli barna í félagslegu, efnahagslegu og heilsufarslegu tilliti. Johansen og félagar sögðu jafnframt að reglurnar virtust hafa gagnast vel til að róa áhyggjufulla foreldra og kennara pegar farið var í að opna skólana að nýju.

\section{Gæði kennslu}

Á pessum tíma var mat á gæðum kennslu trúlega ekki efst á verkefnalista fagfólks í íslenskum skólum pví athygli flestra beindist að pví að ná utan um allt og alla við óvæntar kringumstæður. Alla jafna er starfsfólk skólanna pó mjög ánægt með sitt starf. Grunnskólakennarar sem tóku pátt í rannsókninni Starfshættir í grunnskólum 2008-2013 voru pað til að mynda; yfir 90\% peirra töldu kennsluna vera í heild mjög góða eða yfirleitt góða, en innan við 10\% að hún væri í meðallagi eða henni væri áfátt (Ingvar Sigurgeirsson, Amalía Björnsdóttir, Gunnhildur Óskarsdóttir og Kristín Jónsdóttir, 2014). 
Nú eru forgangsröðun og áherslur í skólastarfi aðkallandi viðfangsefni vegna áhrifa faraldursins á allt samfélagið. Í fyrrnefndri rannsókn, sem oft er kölluð Starfsháttarannsóknin, var grunnskólastarf skoðað frá mörgum sjónarhornum. Niðurstöður Starfsháttarannsóknarinnar varðandi áherslupætti í menntun grunnskólanemenda sýndu að starfsfólk skóla taldi að mjög mikla áherslu ætti að leggja á að efla sjálfsmynd nemenda. Sá kostur lenti efst á lista á meðan áhersla á námsárangur lenti í 6. sæti (Amalía Björnsdóttir og Kristín Jónsdóttir, 2014). Foreldrar voru sama sinnis pví sjálfsmyndin varð í efsta sæti og námsárangur í 5 . sæti á lista peirra yfir áherslupætti í menntun grunnskólanemenda. Nemendur í 7.-10. bekk voru líka beðnir um að leggja mat á áherslupætti en orðalag var að hluta til annað en í spurningunum til hinna fullorðnu. Unglingarnir svöruðu líka nokkuð á annan veg. Mikilvægast pótti peim að í starfi grunnskóla væri lögð áhersla á að öllum nemendum liði vel, en í öðru sæti hjá peim kom áhersla á góðan námsárangur.

Væntingar til skólastarfs og kennara endurspeglast að ýmsu leyti í peim áherslupáttum sem fyrr voru nefndir. Pær taka til margra og mismunandi pátta til viðbótar við hið augljósa hlutverk kennara að miðla og stýra námi nemenda í tilteknum aldurshópi eða ákveðnum faggreinum. Í skrifum Hermínu Gunnpórsdóttur (2016) um fjölbreytileika og kennarastarfið dregur hún fram að kröfur séu gerðar um mismunandi nálganir grunnskólakennarans í kennslu pví engin ein leið henti öllum. Kennsla sé mun margpættara starf en fyrir nokkrum áratugum, og pví purfi að huga vel að hvernig kennsluháttum sé hagað og hvaða kennsluaðferðir séu valdar hverju sinni.

Skólar eru líka mikilvægur félagslegur vettvangur fyrir börn og unglinga. Ný rannsókn á félagstengslum íslenskra barna og unglinga, sem byggir á spurningalistum sem lagðir voru fyrir í 6. , 8. og 10. bekk, leiddi í ljós að flest eru pau með góð tengsl við foreldra, vini og skóla (Ársæll Már Arnarsson, Sigrún Daníelsdóttir og Rafn Magnús Jónsson, 2020). Pau sem á annað borð eru með einhver slök tengsl, hafa pau oftast nær aðeins á einu sviði og pá oftast við vini. Höfundar hafa bent á að um 3\% íslenskra unglinga hafi slök félagstengsl á öllum sviðum, við foreldra, vini og skóla. Pó 3\% virðist í fljótu bragði lág tala eru um 700 börn og unglingar á bak við hana.

\section{Jafnrétti til náms}

Í bandarískri yfirlitsgrein er sjónum beint að pví að reynsla kennara af fjarkennslu í fyrstu bylgju COVID-19 muni nýtast vel pegar næst kemur að pví að loka purfi skólum (Morgan, 2020). Bent er á lokanir geti aukið á ójöfnuð, erfitt sé að mæta pörfum fátækra barna sem hafi takmarkaðan aðgang að tölvum sem og pörfum barna sem purfa sérkennslu sem ekki verði veitt með jafn áhrifaríkum hætti í fjarkennslu sem staðkennslu. Pekking og reynsla kennara af fjarkennslu og netnámi sé dýrmæt en stundum purfi að hugsa út fyrir boxið til að ná til nemenda. Höfundur nefnir dæmi um að skólar í Los Angeles hafi samið við staðbundnar sjónvarpsstöðvar svo kennarar gætu miðlað efni til nemenda sinna í sjónvarpsútsendingum.

Íslensk meistararitgerð, sem byggir á viðtölum sem tekin voru við 13 kennara í einum grunnskóla á landsbyggðinni og tveimur á höfuðborgarsvæðinu í fyrstu bylgju COVID-19, leiddi í ljós að mismunur var á milli grunnskóla landsins varðandi viðveru, fyrirkomulag náms og áherslur (Ylfa G. Sigurðardóttir, 2020). Fram kom að kennararnir sem pátt tóku áttu auðvelt með aðlaga sig að nýjum kröfum í starfi en höfðu áhyggjur af að sérkennsla féll niður og margvísleg sérpjónusta við nemendur stöðvaðist. Höfundur vísar til pess í lokakafla ritgerðarinnar að íslensk menntastefna eins og hún birtist í Aðalnámskrá grunnskóla (Mennta- og menningarmálaráduneyti, 2013) sé stefna um skóla án aðgreiningar. Hún bætir við hvort ekki purfi að vera til viðbragðsáætlun frá menntaog menningarmálaráduneytinu pegar óvissuástand sem petta kemur upp; áætlun sem líkja megi við haldreipi fyrir skólafólk svo uppfylla megi sem best kröfur grunnskólalaga um skólaskyldu og jafnrétti til náms. 
Markmiðsgreinin eða 2. grein laga um grunnskóla nr. 91 frá árinu 2008, sem meðal annars er grundvöllur Aðalnámskrár grunnskóla, hljóðar svo:

Hlutverk grunnskóla, í samvinnu við heimilin, er að stuðla að alhliða proska allra nemenda og pátttöku peirra í lýðræðispjóðfélagi sem er í sífelldri próun. Starfshættir grunnskóla skulu mótast af umburðarlyndi og kærleika, kristinni arfleifð íslenskrar menningar, jafnrétti, lýðræðislegu samstarfi, ábyrgð, umhyggju, sáttfýsi og virðingu fyrir manngildi. Pá skal grunnskóli leitast við að haga störfum sínum í sem fyllstu samræmi við stöðu og parfir nemenda og stuðla að alhliða proska, velferð og menntun hvers og eins.

(Lög um grunnskóla nr. 91/2008)

Í lagagreininni er kveðið á um að starfshættir grunnskóla skuli mótast af jafnrétti og oft er til pessa vísað í umræðum um jafnrétti grunnskólabarna til náms. Fáir myndu draga í efa að skólum bæri skylda til að viðhafa og viðhalda jafnrétti í störfum sínum. Aðeins veikara orðalag er viðhaft par sem segir að grunnskóli skuli leitast við að haga störfum sínum í sem fyllstu samræmi við stöðu og parfir nemenda. Petta er umhugsunarvert í ljósi pess að grunnskólastarf var endurskipulagt með hraði, við fordæmalausar aðstæður, par sem stjórnendur skóla höfðu fátt til að styðjast við.

Sjónarhorn jafnréttis er skarpt í nýrri rannsókn á áhrifum COVID-19 á írska grunn- og framhaldsskólanema. Orla Doyle, sem gerði rannsóknina fyrir opinbera stofnun í stefnumótun, skrifar að eldri rannsóknir hafi sýnt að stéttarstaða foreldra hafi áhrif á hvernig börnum gangi í námi við óvenjulegar og erfiðar aðstæður eins og COVID-19; börn af lægri stéttum verði verst úti og komi par margt til, til dæmis séu meiri líkur á að foreldrar af lægri stéttum missi vinnuna en peir sem eru í efri lögum samfélagsins (Doyle, 2020). Rannsókn hennar byggir á spurningakönnun sem lögð var fyrir 6. apríl og svarað af 458 foreldrum. Niðurstaðan er að pegar skólar loki sé menntun foreldra mjög ráðandi páttur varðandi hvernig börnum og ungmennum gengur í námi sínu. Foreldrar beiti ólíkum og misgóðum aðferðum við að aðstoða börn við námið heima og meira menntaðir foreldrar hafi par forskot. Einnig fái peir meira menntuðu betri námsgögn frá kennurum og nýti frekar aðgang að námsefni frá yfirvöldum. Рað dragi sundur með börnum sem eiga mikið menntaða foreldra og peim sem eiga lítið menntaða foreldra og skólalokanir til langs tíma geti pví haft ófyrirséðar afleiðingar.

\section{Mismunandi aðstæður heima}

Í breskri rannsókn sem beindist einnig að jafnrétti eða ójöfnuði vegna lokunar skóla í fyrstu bylgju COVID-19 voru foreldrar 4.482 barna spurðir um pann tíma sem börnin vörðu til náms heima við og um stuðning sem pau fengu frá skólunum með fjarkennslu, námsgögnum eða öðru (Bayrakdar og Guveli, 2020). Fram kom að margt hafði áhrif; börn frá fátækum heimilum, börn einstæðra foreldra, börn foreldra með litla menntun og börn af pakistönskum og bangladesskum uppruna stunduðu námið heimavið í færri klukkustundir á viku eða marktækt minna en skólafélagarnir pann tíma sem skólarnir voru lokaðir. Meiri áhrif en fyrrnefnt hafði pó stuðningur skólanna við nám nemenda sinna. Athygli vekur að 9,3\% barnanna fengu ekkert frá sínum skólum til að geta stundað námið heima. Niðurstöður leiddu í ljós, hvað stuðning skólanna varðar, að mest munaði um fjarkennslu. Skýrt dæmi um mismunun var að börn af pakistönskum og bangladesskum uppruna voru líklegri en önnur börn til að fá engan stuðning, pað er vera í skólum sem ekkert gerðu fyrir nemendur á meðan lokað var. Pau barnanna af pakistönskum og bangladesskum uppruna sem hins vegar fengu fjarkennslu stunduðu námið heimavið af sama kappi og jafnaldrarnir. Pannig vógu úrræði skólanna pyngst og vel upp á móti félagslegum páttum par sem nemendur fengu fjarkennslu og námsefni að vinna úr. Bayrakdar og Guveli (2020) hittu naglann á höfuðið með eftirfarandi orðum: Par sem skólar gegna lykilhlutverki við að skapa jöfn tækifæri, er tilfærsla náms frá skólum til heimila líkleg til að auka ójöfnuð í menntun barna og unglinga.

Staða foreldra hefur áhrif á tengsl peirra við skóla barna sinna. Í norskri rannsókn kom fram að menntaðir foreldrar ættu auðveldara með að taka pátt í samstarfi við skóla en peir sem minni 
menntun hafa (Bæck, 2009). Niðurstöður, sem byggja á svörum frá um 3500 foreldrum barna í 20 grunnskólum, sýna að upplifun íslenskra foreldra er að mörgu leyti sambærileg (Kristín Jónsdóttir, Amalía Björnsdóttir og Bæck, 2017). Menntaðir foreldrar gera meiri kröfur til skólanna en peir sem litla menntun hafa. Foreldrar hafa líka mismikla möguleika á að hafa áhrif á skólastarfið og til að fá stuðning fyrir börn sín. Einstæðar mæður eru líklegri en aðrir foreldrar grunnskólabarna til að upplifa áhrifaleysi og að fá ekki pann stuðning sem pær telja börn sín purfa á að halda, samkvæmt fyrrnefndri rannsókn.

Breytingar á skólastarfi hérlendis á liðnu vori og minni viðvera barna í skólum jók pressuna á íslenska foreldra sem margir upplifðu togstreitu milli starfa sinna og foreldrahlutverks, samkvæmt rannsókn Auðar Magndísar Auðardóttur og Önnudísar Gretu Rúdólfsdóttur (2020). Pær unnu úr 97 sögum frá foreldrum, aðallega mæðrum. Rannsóknaraðferðin byggði á að pátttakendur fengu upphaf sögu um foreldri tveggja skólabarna, luku við að semja söguna og byggðu par á pekkingu sinni, viðhorfum og gildismati. Rannsóknin varpar ljósi á pær fjölmörgu skyldur sem pátttakendur töldu ábyrga foreldra verða að sinna, svo sem að vera vel skipulagðir, nákvæmir og virkir í námi barna sinna.

\section{Áhrif COVID-19 til framtíðar}

Ef að líkum lætur eru margar nýjar rannsóknir á áhrifum COVID-19 í gangi og birtast vonandi fljótt svo skólafólk geti nýtt sér niðurstöður til leiðbeiningar par sem ekki sér fyrir endann á faraldrinum. Fjölmargir skemmtilegir pistlar frá fræðimönnum og alls konar fagfólki hafa pegar birst með pælingum og ábendingum um hvað megi læra af fyrstu bylgjunni og hvert beri að stefna.

Í pistli sem háskólakennari og valinn kennari ársins 2015 í Bandaríkjunum skrifuðu saman í júní sîðastliðnum, leggja pau út af umræðum um hvernig hægt verði að láta skólabörnin vinna upp allt sem tapaðist á liðnu vori (Mehta og Peeples, 2020). Pau leggja til að skólafólk varist að einblína á að vinna upp tap og ráðleggja að pað taki Marie Kondo á námskrána; noti aðferðir japanska tiltektarsnillingsins til að forgangsraða svo pað sem mikilvægast er fái óskipta athygli.

Pasi Sahlberg (2020), sem meðal annars var ráðgjafi Reykjavíkurborgar við mótun nýrrar menntastefnu, sagði í pistli á liðnu sumri flesta rannsakendur vera sammála um að nám heimavið hefði aukið á pann ójöfnuð sem fyrir var: Börn sem hefðu mesta pörf fyrir skólann, hefðu trúlega liðið mest fyrir pað pegar skólum var lokað. Hann minnti svo á hið augljósa sem okkur hættir stundum til að gleyma: Börn munu halda áfram að læra jafnvel pó peim sé ekki kennt.

Markmið pessarar rannsóknar er að draga upp yfirlitsmynd af grunnskólakennslu á tíma fyrstu bylgju COVID-19. Kastljósinu er beint að viðhorfum kennara og skólastjórnenda og mati peirra á aðstæðum til náms og gæðum kennslu, á samskiptum við foreldra og tengslum við heimilin.

\section{Rannsóknaraðferð}

\section{Pátttakendur}

Skólastjórnendur í grunnskólum og grunnskólakennarar, par með taldir sérkennarar, voru pátttakendur í pessari rannsókn. Peir svöruðu spurningakönnun sem Menntavísindastofnun Háskóla Íslands sendi út 27. apríl 2020 til starfsfólks allra grunnskóla í landinu.

Starfandi grunnskólar á Íslandi voru 170 árið 2019 samkvæmt gögnum Hagstofu Íslands. Netfanga starfsfólks skóla var aflað af vefsíðum grunnskóla og fór spurningakönnunin með boði um pátttöku til 157 skóla eða á 8597 netföng.

Könnunin var opin frá 27. apríl til 26. maí. Svör bárust frá 2.719 starfsmönnum grunnskóla, úr 151 grunnskóla. 
Alls voru 45.904 grunnskólanemendur á Íslandi árið 2018. Skólarnir par sem stjórnendur svöruðu voru samtals með um 36.167 nemendur pað sama ár. Ef hlutfallsleg skipting nemenda á milli skóla hefur ekki breyst mjög mikið er í rannsókninni unnið með svör frá stjórnendum skóla sem um 79\% íslenskra grunnskólanema sækja.

\section{Spurningakönnun}

Spurningar í könnuninni snertu á einn eða annan hátt áhrif faraldursins á starf og vinnuaðstæður grunnskólakennara og skólastjórnenda, proskapjálfa og starfsfólks í frístundastarfi. Spurningarnar voru mismargar eftir pví að hvaða starfsmannahópum peim var beint og svarhlutfall varð líka mismunandi.

Spurningum um starfsemi skólans í heild var í flestum tilfellum beint til skólastjóra og aðstoðarskólastjóra. Niðurstöður um pað og fleira í pessari rannsókn byggja á svörum 183 stjórnenda sem starfa í 118 skólum.

Svör bárust frá 1.582 kennurum. Fjöldi starfsmanna við kennslu eftir skólum liggur ekki fyrir en ljóst er að svörun peirra er ójöfn eftir skólum og pví ber að taka niðurstöðum sem byggja á svörum peirra með nokkrum fyrirvara. Hluti skýringarinnar kann að vera að póstkerfi skólanna eru ólík og könnunin hefur verið mislíkleg til að festast í ruslpóstvörnum. Svarhlutfall könnunarinnar er 33,5\% sé litið til starfsfólks við kennslu.

Í pessari rannsókn snúast spurningar til kennara mest um viðhorf og mat á kennslu og aðstæðum í fyrstu bylgju COVID-19, á samskiptum við foreldra og tengslum við heimilin. Gild svör grunnskólakennara við pessum spurningum voru 971-1003, svo pau gefa allgóða mynd af viðhorfum kennara á heildina litið, með peim fyrirvara um dreifingu svara sem um var getið.

\section{Úrvinnsla}

Engin sérstök siðferðileg álitamál tengjast framkvæmd rannsóknarinnar; ekki var safnað viðkvæmum persónugreinanlegum upplýsingum og pátttakendur voru upplýstir um að peir mættu hafna pátttöku og sleppa einstökum spurningum.

Spurningalistinn var sendur út af Menntavísindastofnun Háskóla Íslands. Öll svör skráđust inn í forrit en voru sîðan sett í SPSS og Excel án allra persónugreinanlegra upplýsinga. Reiknuð var lýsandi tölfræði.

\section{Niðurstöður}

Langflestum grunnskólum var haldið opnum en viðvera nemenda minnkuð nokkuð í fyrstu bylgju COVID-19, og einstaka skóli purfti að loka tímabundið. Um 92\% grunnskóla voru opnir með peim takmörkunum sem hæfilegar póttu á hverjum stað. Skipulag á viðveru nemenda var mismunandi milli skóla og milli sveitarfélaga en allir væntu pess að nemendur lærðu heima, pað er að segja lærðu heimavið pegar fjarkennsla var og sinntu einnig hefðbundnu heimanámi.

\section{Mikil ánægja með kennslu en minni með pátttöku foreldra}

Skólastjórnendur voru gríðarlega ánægðir með hvernig kennslan gekk pennan tíma og tóku í mati sínu væntanlega mið af peim sérstöku aðstæðum sem voru við lýði, sjá Mynd 1 . Hátt í helmingur stjórnenda eða 49\% sagði kennsluna yfirleitt hafa verið í góðu lagi og 39\% til viðbótar sögðu að hún hefði í heild verið mjög góð. Kennarar voru ögn varkárari eða gagnrýnni en $78 \%$ peirra töldu að kennslan hefði verið góð eða mjög góð. 


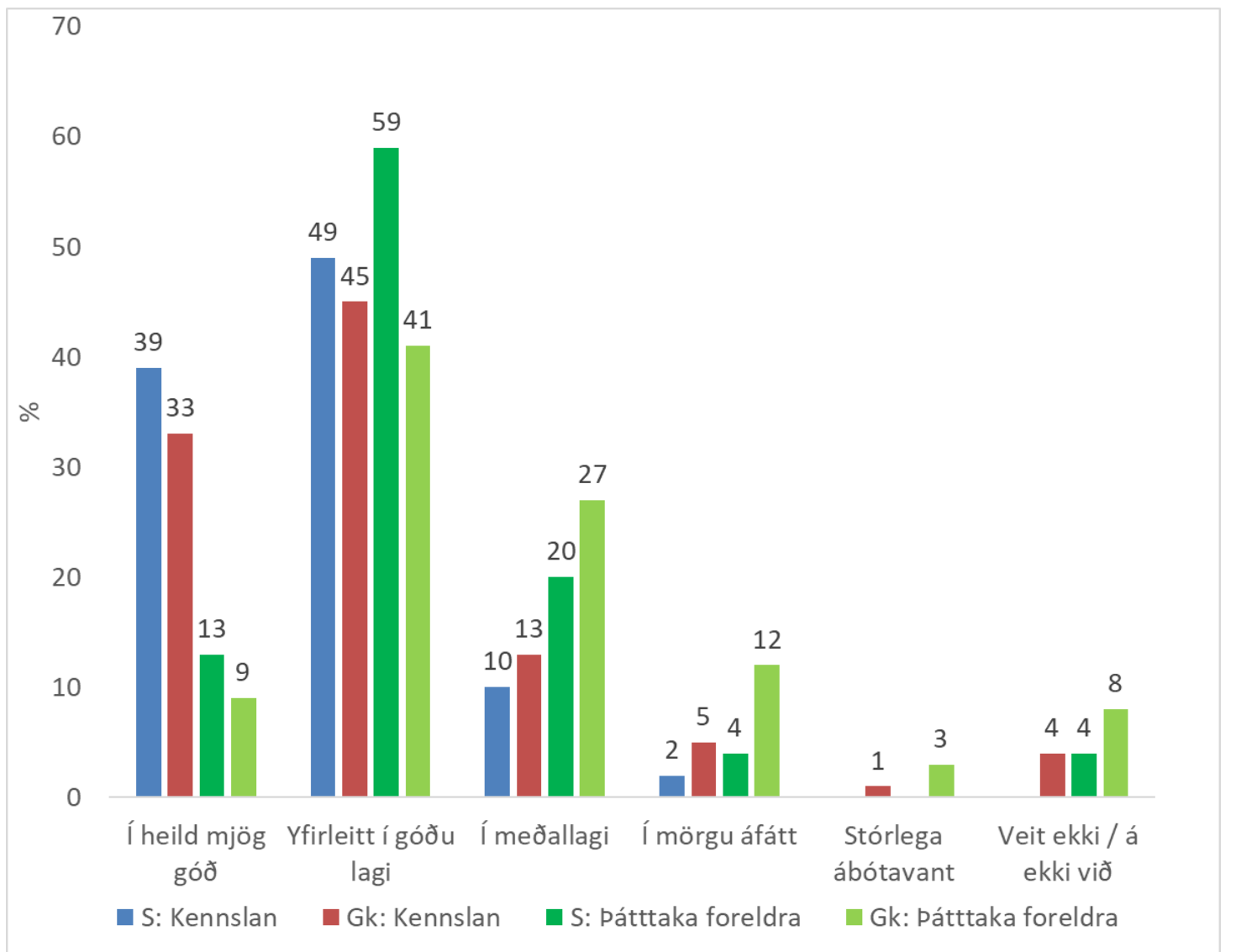

Mynd 1. Mat grunnskólakennara (Gk) og skólastjórnenda (S) á gæðum kennslu og pátttöku foreldra í námi barna sinna í fyrstu bylgju COVID-19.

Á hinn bóginn var skólafólkið ekki eins ánægt með pátttöku foreldra í námi barna sinna og pað var með kennsluna. Bæði stjórnendur og kennarar töldu pátttöku foreldra í námi barna sinna yfirleitt í góðu lagi, samanber Mynd 1. Einungis 13\% stjórnenda töldu pó að pátttaka foreldra í námi barna sinna væri mjög góð, samanborið við að 39\% sögðu kennsluna vera mjög góða. Kennarar voru sama sinnis og stjórnendur, peir töldu kennsluna betri en pátttöku foreldra ef svo má segja. Um helmingur kennara taldi að pátttaka foreldra hefði verið góð. Pá er vert að nefna að $27 \%$ kennara töldu að pátttaka foreldra hefði einungis verið í meðallagi og 15\% töldu pátttöku peirra hafa verið áfátt.

\section{Mæting nemenda var misjöfn}

Mjög vel gekk að skipuleggja viðveru nemenda í skólunum að mati 64\% skólastjórnenda og frekar vel sögðu um 28\% til viðbótar. Mæting nemenda var líka alla jafna góð. Pó er ástæða til að nefna að mæting nemenda á yngsta og miðstigi grunnskóla var pónokkuð betri en mæting nemenda á unglingastigi. Ef nemendur mæta undir $40 \%$ af peim tíma sem peim er ætlað að mæta má segja að mæting peirra sé verulega slök. Mæting um 5\% nemenda á yngsta stigi og um 7\% nemenda á miðstigi var verulega slök að mati stjórnenda. Hins vegar var mæting um $14 \%$ nemenda á unglingastigi mjög slök eða undir $40 \%$ af pví sem til var ætlast.

Ennfremur töldu skólastjórnendur að börn af erlendum uppruna og börn sem hafa veikt bakland eða búa við erfiðar félagslegar aðstæður hefðu mætt áberandi verr en skólasystkin peirra. Um 40\% skólastjórnenda töldu að mæting barna af erlendum uppruna hefði versnað meira en mæting annarra nemenda í fyrstu bylgju COVID-19. Einnig taldi hátt í helmingur stjórnenda (46\%) að mæting barna sem búa við erfiðar aðstæður hefði versnað meira en annarra nemenda. Einungis $2 \%$ stjórnenda töldu að mæting pessara nemendahópa hefði batnað. 


\section{Auðvelt eða erfitt samstarf við foreldra}

Svör kennara og skólastjórnenda varðandi samstarf við foreldra vísuðu í sömu átt en punginn í svörunum var mismunandi. Samstarfið reyndist kennurum greinilega erfiðara, sjá Mynd 2.

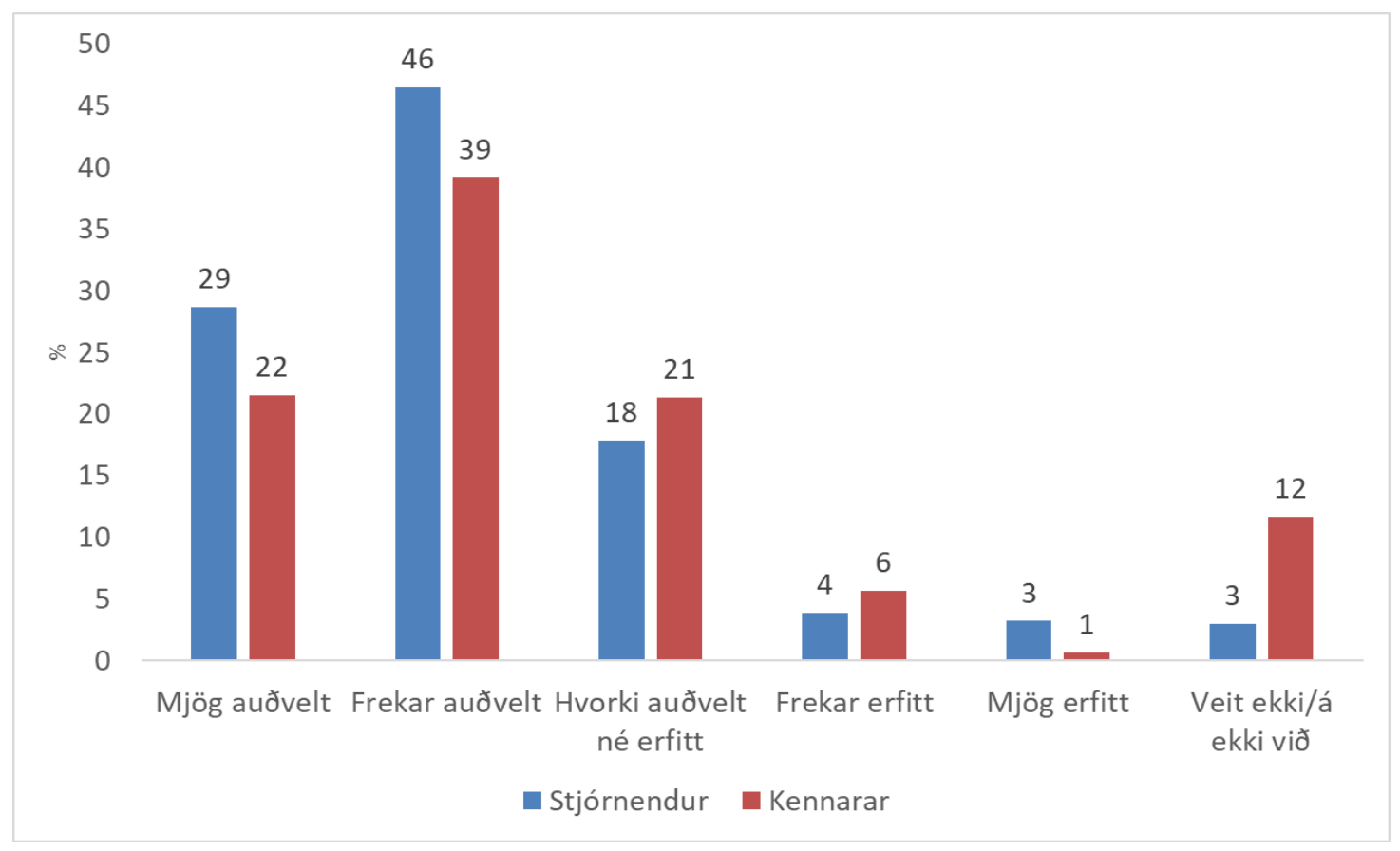

Mynd 2. Mat grunnskólakennara og skólastjórnenda á samstarfinu við foreldra nemenda.

Á Mynd 2 má sjá að um 75\% stjórnenda sögðu samstarfið við foreldra hafa verið mjög eða frekar auðvelt en á sömu skoðun var $61 \%$ kennara. Nokkuð stór hópur kennaranna eða $28 \%$ sögðu samstarfið hafa verið erfitt eða hvorki auðvelt né erfitt.

Í spurningakönnuninni kom fram að fagfólkið lagði sig fram um að rækta samskiptin við heimilin. Foreldrar leituðu eftir stuðningi og ráðgjöf sögðu 43\% stjórnenda og sama sinnis voru um 47\% kennara. Ánægjulegt er að fagfólkið fékk líka athygli og stuðning frá foreldrum, 55\% stjórnenda töldu svo vera og um $40 \%$ kennara.

\section{Faglegt starf var tímafrekt}

Рað tók sannarlega tíma að bregðast við í fyrstu bylgju COVID-19, rækta tengslin við heimilin og upplýsa foreldra. Einnig tók undirbúningur kennslu og kennslan sjálf líka meiri tíma en venjulega að mati kennara, sjá Mynd 3. 


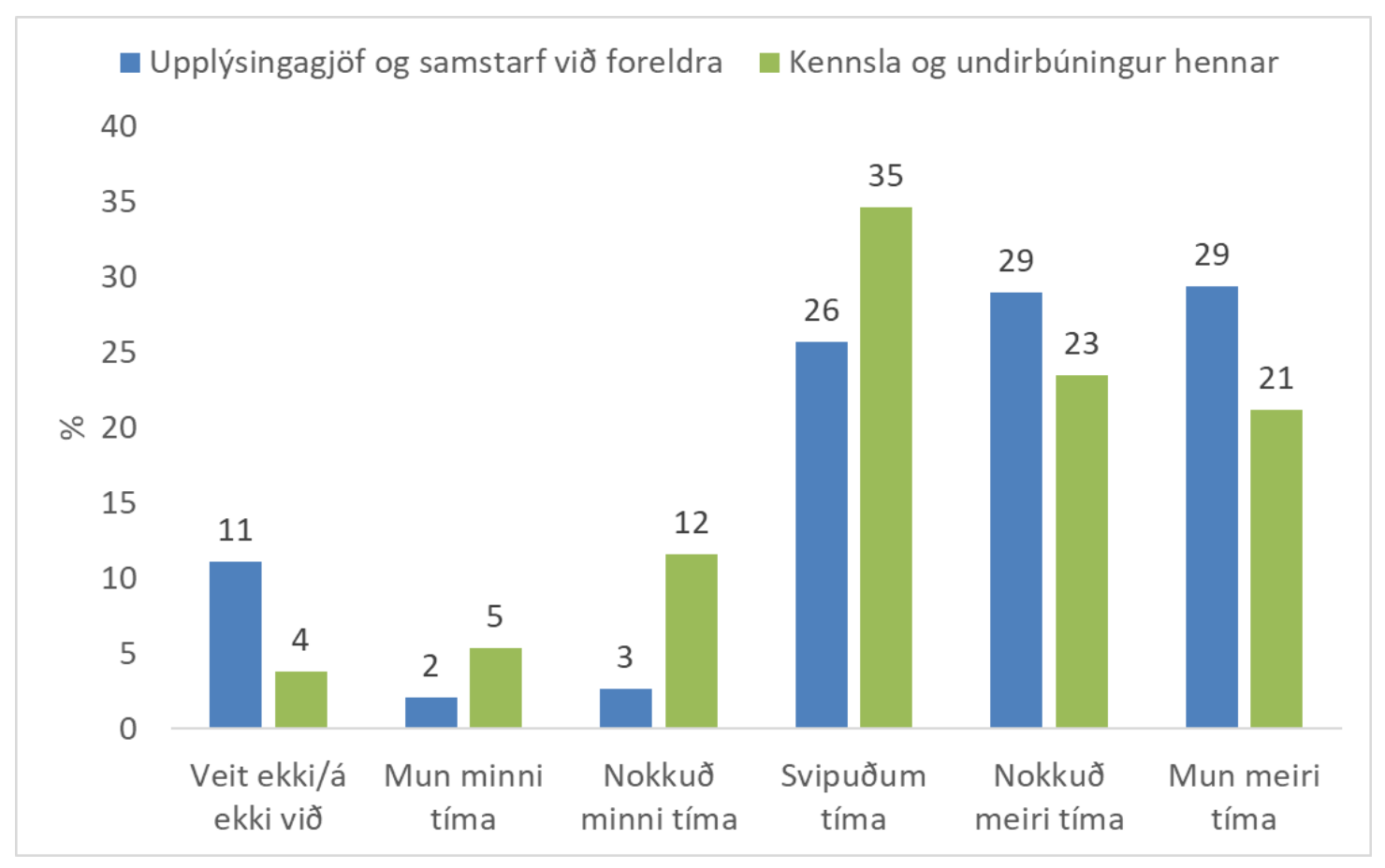

Mynd 3. Mat grunnskólakennara á peim tíma sem peir notuðu í kennslu og undirbúning hennar annars vegar og í upplýsingagjöf og samstarf við foreldra hins vegar.

Pað er ljóst af svörum kennara að vinnuálag á pá jókst verulega í fyrstu bylgjunni ef einungis er litið til pess tíma sem peir unnu að nauðsynlegum páttum í störfum sínum. Mynd 3 talar sínu máli en $44 \%$ kennara eyddu meiri tíma en venjulega í undirbúning kennslu og kennsluna sjálfa. Um $58 \%$ kennara eyddu meiri tíma í upplýsingagjöf og samstarf við foreldra. Í svörum grunnskólastjórnenda kom fram að 68\% peirra töldu sig hafa eytt meiri tíma í upplýsingagjöf og samstarf við foreldra en í venjulegu ári.

\section{Raddir kennara}

Einni opinni spurningu var beint til kennara og hljóðaði hún svo: Viltu nefna eitthvað sérstakt varðandi tengsl við heimilin og nám nemenda heimavið? Við henni bárust 254 svör. Af peim má ráða að upplifun kennara var mjög mismunandi.

Nokkrir lýstu álagi í samskiptum við foreldra vegna pess að mikið purfti að leiðbeina peim og nemendum:

Foreldrar stundum ágengir varðandi pjónustu við svar á tölvupóstum og annað. Í mínu tilfelli var ég á tímabili að kíkja á t-póstinn minn 5x á dag til að tryggja að nemendur væru að ná að skilja og skila verkefnum.

Margir lýstu pví að samskiptin við flesta foreldra hefðu batnað og einn staðhæfði að „fólk er jákvæðara og kurteisara í viðmóti við kennara“. Вæði jákvæð og neikvæð svör bentu til pess að samskiptin hefðu aukist við foreldra á heildina litið og að sumir kennarar hefðu fengið hrós og viðurkenningu fyrir sín störf.

Fram komu skiptar skoðanir varðandi pátttöku foreldra í námi barna sinna. Eitt svarið var: „Ég tel að petta hafi á vissan hátt veitt foreldrum meiri innsýn inn í nám barnanna og gert pá að meiri pátttakendum.“ Annar taldi hættu á „að virkir foreldrar hjálpi of mikið eða læri fyrir nemendur“. Margir nefndu að foreldrar hefðu gert sitt besta en aðstæður peirra til að styðja börn sín í námi væru mismunandi. 
Margir kennarar minntust á mismunandi heimilisaðstæður barna og unglinga og að pær hefðu áhrif á hvernig nemendur gætu stundað námið. Nefnt var að á sumum heimilum væri enginn fullorðinn heima og börnin ættu ein að reyna að sinna náminu en á öðrum heimilum væru margir heima sem gæti líka verið snúið. Einn orðaði pað svo:

Að sjálfsögðu voru mismunandi áskoranir hjá nokkrum heimilum t.d. einstæðra foreldra og pá jókst álagið á heimilinu, p.e. á heimadögum hjá nemendum. Eins gerir maður sér ekki grein fyrir tölvukosti eða aðgengi peirra á heimilum pegar margir eru heima og nota sömu tæki.

Nokkur svör sýndu að kennarar töldu að peir hefðu fyrst misst samband við pá nemendur sem stóðu pegar höllum fæti í náminu. Vísuðu pau svör einkum til nemenda á unglingastigi. Einn orðaði pað svo: „Í heildina virðast peir nemendur sem stóðu tæpt fyrir COVID-19 líka hafa verið fyrstir til að heltast úr lestinni í COVID-19.“

Nokkrir nefndu börn og unglinga sem búa við erfiðar félagslegar aðstæður. Pau mættu verr í skólann en skólasystkinin eins og fyrr var nefnt. Pessi orð kennara lýsa vel áhyggjum og umhyggju kennara:

Áhyggjur af börnum með veikt bakland, pau drógust frekar aftur úr prátt fyrir fjarkennslu par sem stuðningur við pau var minni/athygli minni. Pau börn upplifa erfiðleika núna, hafa ekki fengið neinn andlegan stuðning né sérkennslu vegna aðstæðna undanfarnar vikur. Hefði verið hægt að gera betur í tengslum við afleysingu fyrir sérkennslu/námsráðgjöf, kannski ekki hugað nægilega að mikilvægi pess.

Umhugsunarvert er líka að kennarar nefndu að erfitt væri að átta sig á hvernig börn af erlendum uppruna sinntu náminu heima fyrir og af hverju mætingin væri eins slök og hún var. Um petta sagði einn kennari:

Er mikið með nemendur af erlendum uppruna og næ ekki sambandi við suma og fæ ekki miklar upplýsingar hvað mikið er unnið heima. En samt gott hljóð í flestum foreldrum og börnum.

Sumir kennaranna nefndu að úthald hefði vantað hjá foreldrum. Nefnt var til dæmis að foreldrar hefðu beðið um viðbótarnámsefni fyrir börn sín en svo hefði pað ekkert verið notað. Nokkrir nefndu að heimalestur barna hefði minnkað. Einn kennari orðaði petta svo:

Mér fannst pátttaka foreldra mun meiri í byrjun, p.e. fyrir páskaleyfi. Eftir páskaleyfi var eins og úthald skorti eða að foreldrar eygðu venjulegan skóladag í augsýn en samt voru 3 vikur eftir!

Loks er ástæða til að draga fram að mörg svör kennara voru á kennslufræðilegum nótum, veittu innsýn í hvernig nám nemenda hafði verið skipulagt, kosti og galla og hvaða lærdóm mætti af pví draga. Í svörunum var oft tengt við samstarfið við heimilin um námið. Petta svar var ítarlegt og dregur fram nokkur athyglisverð atriði:

Fannst tengslin aukast, settum börnunum fyrir „heimaskólaverkefni“ par sem foreldrar tóku stundum pátt. Finnst gott að setja meiri ábyrgð á heimili að fylgjast með og taka pátt og nú gafst kannski meira rými og tími fyrir foreldra að gera pað. Fannst líka gott að hafa minni námshópa par sem maður gat sinnt hverju og einu barni miklu betur og um leið meiri samskipti heim. Fannst líka styttri skóladagur skila meiri árangri, var hnitmiðaðri og afslappaðri. 


\section{Áhyggjur foreldra af námsárangri og lídan barna sinna}

Grunnskólakennarar og stjórnendur töldu foreldra frekar hafa áhyggjur af líðan en námsárangri barna sinna á pessu tímabili, sjá Mynd 4. Stjórnendur töldu áhyggjur foreldra meiri en kennarar gerðu. Pað kann að skýrast af pví að umsjónarkennarar eru mest í tengslum við foreldra barna í sínum bekk eða nemendahópi en stjórnendur eru oft í sambandi við foreldra barna í mörgum umsjónarhópum og öll alvarlegri mál rata inn á peirra borð.

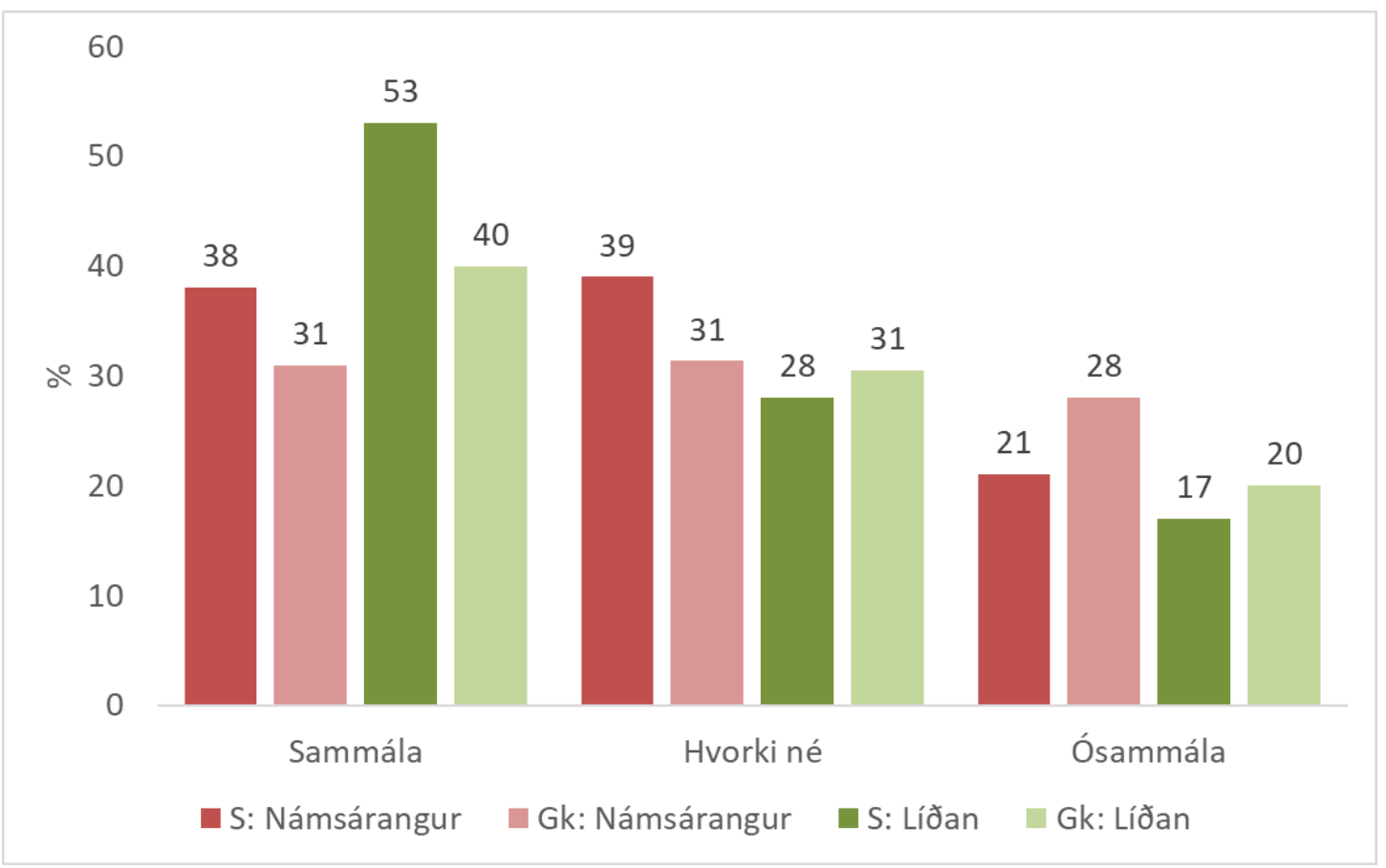

Mynd 4. Svör grunnskólakennara (Gk) og skólastjórnenda (S) um hversu sammála eða ósammála peir eru fullyrðingum um að foreldrar hafi áhyggjur af námsárangri eða líðan barna sinna.

Á Mynd 4 má sjá að 38\% stjórnenda og 31\% kennara töldu foreldra hafa haft áhyggjur af námsárangri barna sinna. Nánast jafnmargir úr bádum hópum töldu foreldra hvorki áhyggjufulla né áhyggjulausa hvað varðar námsárangurinn. Um $28 \%$ kennara töldu foreldra ekki hafa áhyggjur af námsárangri á pessum tíma. Hins vegar er ljóst að fagfólkið taldi foreldra hafa áhyggjur af líðan barnanna. Um $53 \%$ skólastjórnenda töldu svo vera og um $40 \%$ kennara voru sammála um að foreldrar hefðu áhyggjur af líðan barna sinna. Рað er skýr niðurstaða að stjórnendur og kennarar töldu foreldra mun frekar hafa áhyggjur af líðan barna og unglinga en af námsárangri peirra í fyrstu bylgju COVID-19.

\section{Umræða og lokaorð}

Ljóst er af niðurstöðum að skólastjórnendur lögðu allt kapp á að halda uppi kennslu í mars, apríl og maí 2020 pegar fyrsta bylgja COVID-19 gekk yfir hérlendis. Um 92\% grunnskóla voru opnir með peim takmörkunum sem hæfilegar póttu á hverjum stað. Petta var í samræmi við áherslur íslenskra stjórnvalda og sóttvarnareglur hverju sinni en ólíkt pví sem víða var gert í nágrannalöndum, svo sem Noregi, Bretlandi og Írlandi, par sem grunnskólar voru lokaðir vikum saman (Bayrakdar og Guveli, 2020; Doyle, 2020; Johansen o.fl., 2020). Mikilvægt var að útfærslan á viðveru eða mætingu nemenda var ekki miðstýrð hérlendis heldur traust bundið við að samráð skólastjórnenda innan sveitarfélaga leiddi til skynsamlegrar niðurstöðu. Skólastjórar fengu par með mikið svigrúm til að laga sig að aðstæðum og taka ákvarðanir samkvæmt peim og pörfum í nærumhverfinu, sem sannarlega voru mismunandi milli sveitarfélaga og eftir tímabilum í fyrstu bylgjunni. Helsti ókosturinn við að fara pessa leið var að af og til komu fram gagnrýnisraddir og áhyggjur vegna pess að ekki gerðu allir 
skólar eins, en eins og Johansen og félagar (2020) bentu á stuðlaði samræming aðgerða á héraðsvísu í Noregi að pví að sefa áhyggjur jafnt skólastarfsfólks sem foreldra. Sjálfstæði skólanna hérlendis til að taka ákvarðanir á heimavelli á trúlega drjúgan pátt í að 92\% skóla héldust opnir, sem hlýtur að teljast mjög góður árangur og er ein meginniðurstaða rannsóknarinnar.

Önnur meginniðurstaða er að skólastjórnendur voru gríðarlega ánægðir með hvernig tókst að endurskipuleggja kennslu á pessu tímabili en ekki eins ánægðir með pátttöku foreldra í námi barna sinna. Um 88\% skólastjórnenda töldu kennsluna hafa verið mjög góða eða góða, samanber Mynd 1. Kennarar voru ögn hógværari en um $78 \%$ peirra voru sama sinnis. Í mati sínu var fagfólkið væntanlega að taka mið af aðstæðum en ánægjan slagar samt hátt upp í sambærilegar niðurstöður í rannsókn á starfsháttum í íslenskum grunnskólum par sem gagna var aflað í 20 skólum (Ingvar Sigurgeirsson o.fl., 2014). Samkvæmt Starfsháttarannsókninni töldu ríflega 90\% kennara kennslu í sínum grunnskóla í heild vera mjög eða yfirleitt góða. Trú stjórnenda og kennara í pessari rannsókn, á að gæði kennslu í fyrstu bylgju COVID-19 hafi ekki minnkað frá pví sem er í venjulegu ári, er dýrmæt, sérstaklega í ljósi pess að öflugt faglegt starf er tímafrekt. Hátt í helmingur kennaranna (44\%) taldi að undirbúningur kennslunnar og kennslan sjálf hefði tekið meiri tíma í fyrstu bylgju COVID-19 en venjulega, samanber Mynd 3. Í annarri íslenskri rannsókn frá vormánuðum 2020 kom fram að almennt áttu kennarar auðvelt með að aðlaga sig nýjum kröfum í starfinu (Ylfa G. Sigurðardóttir, 2020). Petta hvort tveggja, aðlögunarhæfnin og vinnusemi og metnaður sem kom fram í að verja meiri tíma til starfsins, er til marks um fagmennsku kennara og stjórnenda pegar pörf krafði.

Pónokkur munur kom fram á mati kennara og stjórnenda annars vegar á kennslunni og hins vegar á pátttöku foreldra í námi barna sinna, sjá Mynd 1, og er pað priðja meginniðurstaðan. Bæði kennarar og stjórnendur töldu pátttöku foreldra í námi barna sinna ekki hafa verið jafn góða og kennsluna sem skólafólkið sjálft stýrði. Um $27 \%$ kennara sögðu pátttöku foreldra hafa verið í meðallagi, hvorki góða né slæma, og 15\% kennaranna töldu að henni hefði verið áfátt. Ljóst er að pessar tölur lýsa nokkurri óánægju eða vonbrigðum kennara með frammistöðu foreldra hvað varðar pátttöku peirra í námi barna sinna. Ef pessar niðurstöður eru skoðaðar með hliðsjón af svörum kennara við opinni spurningu má pó segja að kennarar hafi verið óánægðir með pátttöku foreldra af ýmsum og ólíkum ástæðum. Nefnt var að börn fengju ekki nægan stuðning heima fyrir, einnig að aðhald skorti og úthald skorti hjá sumum foreldrum í að styðja börnin. Á móti kom að kennarar nefndu líka að aðstæður foreldra til að taka pátt í námi barnanna væru mjög mismunandi og sumir nefndu að reynslan af COVID-19 hefði veitt peim nýja innsýn í pær og aukið skilning peirra á aðstæðum barna og foreldra. Pessar niðurstöður eru samhljóma annarri nýrri íslenskri rannsókn sem sýndi að foreldrar grunnskólabarna eru ekki einsleitur hópur frekar en börnin sjálf, breytingar á starfsemi skóla komu við fjölskyldur á ólíka vegu og aðstæður til að taka pátt í námi barna og unglinga gátu verið mjög mismunandi, meðal annars vegna vinnu og fjölskylduaðstæðna (Auður Magndís Auðardóttir og Annadís Greta Rúdólfsdóttir, 2020). Íslenskar og erlendar rannsóknir sýna að menntun foreldra getur og skipt verulegu máli pannig að foreldrar með litla menntun séu í verr í stakk búnir til að aðstoða börn sín og styðja við nám peirra (Bæck, 2009; Doyle, 2020; Kristín Jónsdóttir o.fl., 2017). Höfundur pessarar rannsóknar vill einnig draga pann lærdóm af framangreindu að stjórnendur og kennarar purfi að skoða hvort foreldrar geti fengið ný, öðruvísi eða fjölbreyttari tækifæri til pátttöku í námi barna sinna.

Fjórða meginniðurstaða rannsóknarinnar snýst um tengsl heimila og skóla eða samskipti kennara og stjórnenda við foreldra nemenda. Рað er ljóst að tengslin milli grunnskólanna og heimilanna virðast hafa verið frekar sterk á pessu tímabili en pað hafi líka tekið tíma hjá stjórnendum og kennurum að rækta pau. Sex af hverjum tíu kennurum vörðu meiri tíma en venjulega í upplýsingagjöf og samstarf við foreldra. Með hliðsjón af pví sem fyrr var sagt um að kennarar vörðu meiri tíma til undirbúnings og kennslu má ljóst vera að peir unnu á heildina litið töluvert meira en í meðalári. Meirihluta kennaranna fannst samstarfið við foreldra vera auðvelt. Pó reyndi talsvert á, samanber Mynd 2, pví 28\% kennaranna sögðu samstarfið annaðhvort hafa verið erfitt (7\%) eða hvorki auðvelt né erfitt (21\%) sem algengt er að túlka í neikvæðari áttina. Á heildina litið virðist vera sem hallað 
hafi á kennara, samskiptin við foreldra hafi verið peim aðeins erfiðari en skólastjórnendum. Petta rennir frekari stoðum undir að stöðugt vaxandi kröfur séu gerðar til kennara sem fagfólks. Í pví efni hefur athyglin m.a. beinst að pví að kennarastarfið felur í sér svo margt fleira en kennslu og kröfur til kennara um að mæta mismunandi pörfum nemenda hafa aukist á síðustu áratugum (Hermína Gunnpórsdóttir, 2016).

Foreldrar höfðu meiri áhyggjur af líðan barna sinna en námsárangri peirra í fyrstu bylgju faraldursins, að mati kennara og skólastjórnenda, eins og sjá má á Mynd 4. Pessi fimmta meginniðurstaða samrýmist vel fyrri rannsóknum sem sýna að fagfólk skólanna og foreldrar forgangsraða á sama veg og að pessir hópar eru sammála um hvað leggja eigi mesta áherslu á í skólastarfi (Amalía Björnsdóttir og Kristín Jónsdóttir, 2014). Pannig staðfesta pessar niðurstöður að samstaða er enn um pað í samfélaginu að góð líðan barna og unglinga sé forgangsmál. Freistandi er að tengja pað við hollráð frá peim sem hvetja skólafólk til að taka Marie Kondo á námskrána, pegar skólastarf færist í eðlilegt horf, svo aðalatriðin fái óskipta athygli (Mehta og Peeples, 2020).

Sjötta meginniðurstaðan snýst um mætingu nemenda. Pað er sláandi að nemendur á unglingastigi mættu verr en yngri nemendur að mati skólastjórnenda pegar fyrsta bylgja COVID-19 gekk yfir. Peir telja að um 14\% unglinganna hafi mætt undir $40 \%$ af peim tíma sem peir áttu að mæta í skólann. Fjarvera nemenda er auðvitað af ýmsum ástæðum en ekkert augljóst tengt faraldrinum sjálfum skýrir pennan mun milli aldurshópa, og $14 \%$ er hátt hlutfall. Ef til dæmis er miðað við litla unglingadeild með um 24 nemendum í hverjum árgangi pá pýðir petta að um 10 unglingar hafi mætt illa. Vitað er að um 700 grunnskólanemendur í landinu eru í viðkvæmri stöðu par sem félagstengsl peirra eru slök við fjölskyldu, vini og skóla (Ársæll Már Arnarsson o.fl., 2020). Ástand eins og skapast hefur vegna COVID-19 getur klárlega veikt félagstengsl unglinga enn frekar og hitt pá fyrir sem síst skyldi. Pað gefur tilefni til að fylgst verði sérstaklega vel með börnum og unglingum sem mæta illa í skólann vegna kórónufaraldursins. Sum pessara barna og unglinga gætu hreinlega týnst og ekki átt afturkvæmt pví skrefin til baka inn í skólana geta verið mjög pung eftir mikla fjarveru.

Sjöunda og síðasta meginniðurstaða pessarar rannsóknar er að fagfólkið í skólunum hafði nokkrar áhyggjur af nemendum sem tilheyra viðkvæmum hópum. Önnur rannsókn á COVID-19 og íslensku grunnskólastarfi sýndi eins og pessi að kennarar höfðu áhyggjur af að ýmiss stuðningur við nemendur féll niður (Ylfa G. Sigurðardóttir, 2020). Svör kennara við opinni spurningu pessarar rannsóknar sýndu að peir voru oft mjög meðvitaðir um aðstæður nemenda sinna og höfðu áhyggjur af nemendum sem tilheyra viðkvæmum hópum, eru af erlendum uppruna og peim sem hafa veikt bakland. Pessar áhyggjur samrýmdust mati skólastjórnenda á mætingu nemenda í skólann sem alla jafna var góð. Hins vegar töldu um $40 \%$ peirra að mæting barna af erlendum uppruna hefði breyst til hins verra í samanburði við mætingu skólasystkina. Um 46\% stjórnenda sögðu mætingu barna sem hafa veikt félagslegt bakland hafa versnað samanborið við aðra nemendur. Petta er áskorun par sem skólastarf skal vera grundvallað á jafnrétti samanber 2. grein laga um grunnskóla. Skert skólastarf og skólalokanir hafa gjarnan verst áhrif á pá sem viðkvæmir eru fyrir, samkvæmt niðurstöðum erlendra rannsókna sem pegar liggja fyrir um áhrif COVID-19 á skólagöngu barna og unglinga (Bayrakdar og Guveli, 2020; Doyle, 2020; Johansen o.fl., 2020; Sahlberg, 2020). Pannig geta viðbrögð við COVID-19 sem fela í sér skerðingu á skólastarfi aukið ójöfnuð milli barna og unglinga pví menntun er almennt talin stuðla að jafnrétti manna á meðal. Með börn af erlendum uppruna í huga er líka rétt að nefna að foreldrar peirra hafa stundum minni tök á að taka pátt en innfæddir af mismunandi ástæðum. Stundum verður íslenskan sem tungumál skóla að hindrun sem fagfólkið parf að yfirstíga og beita til pess hugkvæmni og frumlegum lausnum eins og kennurum er sérlega lagið að gera (Morgan, 2020). Pessi staðreynd og fleira kallar á að foreldrar fái fjölbreyttari verkefni til að taka pátt í með börnum sínum.

Á heildina litið sýna niðurstöður að kennarar og stjórnendur lögðu mikið á sig til að halda uppi góðri kennslu í grunnskólum landsins í fyrstu bylgju COVID-19. Peir víluðu ekki fyrir sér að leita nýrra leiða, meðal annars með fjarkennslu til viðbótar við veru nemenda í skólunum, pó pað kostaði umtalsverða aukavinnu. Greina má nokkur vonbrigði með samskipti við foreldra pó margir kennarar 
hafi líka upplifað stuðning og hrós frá foreldrum á pessum álagstíma. Samt eru skýrar vísbendingar um að tengsl grunnskóla og heimila hafi trosnað merkilega lítið og frekar styrkst en veikst í fyrstu bylgju COVID-19 pegar á heildina er litið. Pessa ályktun byggir höfundur á niðurstöðum og umræðunni hér að framan en rökin eru prenns konar. Í fyrsta lagi má ljóst vera að starfsfólk skóla lagði sig fram um að halda skólunum opnum og stýra góðri og vel undirbúinni kennslu af fagmennsku um leið og pað fékk skýrari mynd af hvað nemendur búa við mismunandi aðstæður. Pað lagði mikið á sig og uppskar nokkra viðurkenningu. Í öðru lagi virðist sem foreldrar hafi fengið meiri innsýn í fjölbreytt og krefjandi viðfangsefni grunnskólanáms og sýnt kennurum oftast pakklæti og virðingu en í stöku tilfellum pirring og tilætlunarsemi. Áhersla foreldra á góða líðan barna sinna fremur en námsárangur, að mati skólafólksins, er í góðu samræmi við eldri rannsóknir hérlendis. Sjónarmið foreldra og reynslu peirra af skólastarfi í COVID-19 væri áhugavert að skoða í framhaldsrannsókn. Í priðja lagi leiðir rannsóknin í ljós að samskipti heimila og skóla jukust í flestum tilvikum, kennarar og foreldrar unnu saman með margvíslegum hætti og eftir nýjum leiðum. Peir fengu líka ný tækifæri til að skilja hvorir aðra og mismunandi aðstæður barna, í námi jafnt sem á heimilum. Sá galli var á að tengsl kennara við nemendur úr viðkvæmum hópum rofnuðu frekar en við jafnaldra peirra svo neikvæð áhrif fyrstu bylgju faraldursins virðast hafa bitnað harðast á pessum nemendum. Pað er einnig efni í nýja rannsókn.

\section{Pakkir}

Ég pakka skólastjórnendum og grunnskólakennurum sem svöruðu könnuninni fyrir mikilvægt framlag til rannsókna á áhrifum COVID-19 á grunnskólastarf á Íslandi. Einnig pakka ég félögum mínum í COVID-hópnum og á Menntavísindastofnun HÎ fyrir gott samstarf.

\section{COVID-19 did not damage the relationship with families, according to leaders and teachers in compulsory schools}

The first wave of COVID-19 in Iceland lasted from March to May in 2020. Around $92 \%$ of the compulsory schools remained open, albeit with some restrictions in order to minimize the risk of spreading the pandemic amongst school children. These restrictions included grouping students and organising their attendance in school at different times or days. The Ministry of Education, Science and Culture did not organise attendance in school centrally but was active in the discussion of best solutions. Local authorities and school leaders made the decisions, thus solutions diverged between schools and school districts, although all students were expected to study at home to compensate for time not spent at school. Schools also responded by increasing information to parents and almost all of them started some kind of distance teaching to support students when they were supposed to study at home. Neither children nor their parents are a homogeneous group and these changes in compulsory schooling affected families in different ways.

Researchers on the impact of COVID-19 on compulsory schooling and school children have already revealed negative effects. Children belonging to lower SES groups were more likely than other children to lack support from their schools, and during school closures in Britain and Ireland, parents' educational level also influenced the material they received from teachers to assist their children (Bayrakdar \& Guveli, 2020; Doyle, 2020). In Norway schools closed for six weeks in spring 2020 but then gradually opened again. Scientists from health and educational institutions in Norway pointed out that evidence for the effect of school closures on the reduction of COVID-19 disease burden is limited, while the negative consequences of school closures include the real risks of deepening social, economic and health inequities (Johansen et al., 2020). The authorities stated that rules or guidelines, they had provided on safe reopening of schools, were perceived as reassuring for the concerned parents and teachers involved. 
This research builds on answers from school leaders and teachers that participated in an online-survey in April-May 2020. Answers came from 151 compulsory school out of 170 in total in Iceland. The questions focused on teachers' and school leaders' opinions regarding the re-organisation of teaching and learning during the first wave of COVID-19, with special attention to home-school relationship.

Findings showed that teachers and school leaders were fully aware that students' opportunities to study at home were diverse. Even so - or maybe just because of that - they put a lot of effort into keeping the schools open as much as possible, also to provide students with books and tasks to work on at home. Teachers used more time than usual in teaching and in planning and preparing as they had to change the curriculum considerably. They spent additional time on contacting and informing students' families. School leaders and teachers were very content with the teaching in general, but they were less content with parent participation in children's studies. The professionals were concerned about students in vulnerable groups, such as students of immigrant origin or those with weak social background. Those students were more often missing from school than their fellow classmates. The findings reveal a slight disappointment relating to communication with parents during this period, although many teachers and school leaders report that they received support and praise from parents as well. Altogether, findings suggest that home-school relations were strengthened rather than weakened during the first wave of COVID-19.

Key words: COVID-19, home-school relations, compulsory schools, equity, school development.

\section{Um höfund}

Dr. Kristín Jónsdóttir (kjons@hi.is) er kennslukona og dósent í kennslufræði á Menntavísindasviði Háskóla Íslands. Hún gegnir nú starfi forseta Deildar kennslu- og menntunarfræði. Á hennar rannsóknasviði eru nám og kennsla, tengsl heimila og skóla og skólapróun. Hún hefur áralanga reynslu af kennslu og stjórnunarstörfum í grunnskóla.

\section{About the author}

Dr Kristín Jónsdóttir (kjons@hi.is) is an associate professor in pedagogy and didactics, and head of Faculty of Education and Pedagogy at the University of Iceland. Her research fields are teaching and learning, home-school relationship, and school development. She worked for several years as a teacher and headmaster in compulsory schools.

\section{Heimildir}

Amalía Björnsdóttir og Kristín Jónsdóttir. (2014). Viðhorf nemenda, foreldra og starfsmanna skóla. Í Gerður G. Óskarsdóttir (ritstjóri), Starfshattir i grunnskólum við upphaf 21. aldar (bls. 29-56). Reykjavík: Háskólaútgáfan.

Auður Magndís Auðardóttir og Annadís Greta Rúdólfsdóttir. (2020). Chaos ruined the children’s sleep, diet and behaviour: Gendered discourses on family life in pandemic times. Gender, work, and organization. doi:10.1111/gwao.12519

Ársæll Már Arnarsson, Sigrún Daníelsdóttir og Rafn Magnús Jónsson. (2020, maí). Félagstengsl íslenskra barna og ungmenna. Reykjavík: Embætti landlæknis.

Bayrakdar, S. og Guveli, A. (2020, júní). Inequalities in home learning and schools provision of distance teaching during school closure of COVID-19 lockdown in the UK. United Kingdom: ISER, University of Essex. 
Bæck, U.-D. K. (2009). From a distance - how Norwegian parents experience their encounters with school. International Journal of Educational Research, 48(5), 342-351. doi:10.1016/j.ijer.2010.03.004

Doyle, O. (2020, apríl). COVID-19: Exacerbating educational inequalities? Ireland: Public Policy.

Heilbrigðisráðuneytið og mennta- og menningarmálaráðuneytið. (2020, 20. mars). Leiðbeinandi viðmið um íprótta- og æskulýðsstarf í ljósi takmörkunar á skólastarfi og samkomum. Sótt af https://www.stjornarradid.is/efst-a-baugi/frettir/stok-frett/2020/03/20/Leidbeinandi-vidmid-um-ithrotta-og-aeskulydsstarf-i-ljositakmorkunar-a-skolastarfi-og-samkomum/

Hermína Gunnpórsdóttir. (2016). Fjölbreytileiki nemenda og kennarastarfið. Í Dóra S. Bjarnason, Hermína Gunnpórsdóttir og Ólafur Páll Jónsson (ritstjórar), Skóli margbreytileikans: Menntun og manngildi i kjölfar Salamanca (bls. 259-282). Reykjavík: Háskólaútgáfan.

Ingvar Sigurgeirsson, Amalía Björnsdóttir, Gunnhildur Óskarsdóttir og Kristín Jónsdóttir. (2014). Kennsluhættir. Í Gerður G. Óskarsdóttir (ritstjóri), Starfshattir i grunnskólum við upphaf 21. aldar (bls. 113-158). Reykjavík: Háskólaútgáfan.

Ingvi Hrannar Ómarsson. (2020, 8. apríl). Heimaskólinn á tímum Covid-19. Bergmann Guðmundsson (Giljaskóli) [viðtal á Menntavarpi, hlaðvarpi um menntamál]. Sótt af http://ingvihrannar.com/fjarkennsla-atimum-covid-19-bergmann-gudmundsson-giljaskoli/

Johansen, T. B., Astrup, E., Jore, S., Nilssen, H., Dahlberg, B. B., Klingenberg, C., . . Greve-Isdahl, M. (2020, apríl). Infection prevention guidelines and considerations for paediatric risk groups when reopening primary schools during COVID-19 pandemic, Norway, April 2020. Eurosurveillance, 25(22). doi:10.2807/15607917.es.2020.25.22.2000921

Kennarasamband Íslands. (2020, 23. mars). Menntabúðir á neti fyrir skólafólk. Sótt af https:/www.ki.is/ um-ki/utgafa/frettir-og-pistlar/frettir/2020/menntabudir-a-neti-fyrir-skolafolk/

Kristín Jónsdóttir, Amalía Björnsdóttir og Bæck, U.-D. K. (2017). Influential factors behind parents' general satisfaction with compulsory schools in Iceland. Nordic Journal of Studies in Educational Policy, 3(2), 155-164. doi:10.1080/20020317.2017.1347012

Lög um grunnskóla nr. 91/2008.

Mehta, J. og Peeples, S. (2020, 26. júní). Marie Kondo the curriculum [bloggfærsla]. Sótt af https://www. shankerinstitute.org/blog/marie-kondo-curriculum

Mennta- og menningarmálaráðuneyti. (2013). Aðalnámskrá grunnskóla: Almennur hluti 2011: Greinasvið 2013. Reykjavík: Höfundur.

Morgan, H. (2020). Best practices for implementing remote learning during a pandemic. Clearing House: A Journal of Educational Strategies, Issues and Ideas, 93(3), 134-140.

Sahlberg, P. (2020, 3. júní). Five things not to do when schools reopen [bloggfærsla]. Sótt af https://www. shankerinstitute.org/blog/five-things-not-do-when-schools-re-open

UNICEF. (2020, mars). Lykilskilaboð og forvarnaraðgerðir vegna COVID-19 i skólum. Sótt af https://stjornar radid.is/lisalib/getfile.aspx?itemid=5cf16b5a-678f-11ea-945f-005056bc4d74

Ylfa G. Sigurðardóttir. (2020). Grunnskólakennsla á tímum fjöldatakmarkana vegna COVID-19. Sjónarhorn grunnskólakennara (óútgefin meistararitgerð). Háskólinn á Akureyri.

Kristín Jónsdóttir. (2020).

Tengslin við heimilin trosnuðu merkilega lítið í fyrstu bylgju COVID-19 Sjónarhorn stjórnenda og grunnskólakennara

Netla - Veftímarit um uppeldi og menntun: Sérrit 2020 - Um Covid 19.

Sótt af http://netla.hi.is/serrit/2020/covid19/05.pdf

DOI: https://doi.org/10.24270/serritnetla.2020.21 